\title{
De waarde in de accountantsverklaring; Babylonische spraakverwarring geprolongeerd?
}

\author{
Drs. A. Oosenbrug RA, Act. AG
}

\section{Inleiding}

De bewoordingen van de (goedkeurende) accountantsverklaring blijven binnen accountantskringen de gemoederen bezighouden. Recentelijk kwam dit in het MAB weer eens tot uitdrukking door het plaatsen van het artikel 'De waarde in de accountantsverklaring' van de hand van Prof. Dr. A. J. Bindenga. Andere (recente) publikaties omtrent deze materie waren onder meer 'De tekst van de goedkeurende verklaring bij de jaarrekening', gepubliceerd in Radar en voorts Vecht (1987) en Schipper (1988). Gezien het belang van het scheppen van duidelijkheid omtrent de betekenis van de accountantsverklaring, heeft het Nivra zelfs in 1985 een Werkgroep Herziening Verklaringenstelsel in het leven geroepen, waarvan de taakopdracht onder meer als volgt luidt:

'voorstellen te doen voor de bewoording van accountantsverklaringen bij jaarrekeningen en andere verantwoordingen, die reikwijdte en strekking voor zowel gebruikers als beroeps-

\section{Drs. A. Oosenbrug}

RA, Act. Ag, studeerde bedrijfseconomie en accountancy aan de Erasmus Universiteit Rotterdam, en actuariële wetenschappen aan de Vrije Universiteit en de Universiteit van Amsterdam. Werkzaam als controller en actuaris bij Klaverblad Verzekeringen te Zoetermeer en docent 'fiscal accounting' Rijksuniversiteit te Leiden. genoten zo duidelijk mogelijk weergeeft.'

(Krom (1987), pag. 408, curs. ao)

Bindenga meent nu, dat het in de accountantsverklaring gebruiken van de term 'vermogen' enerzijds aanleiding geeft tot onduidelijkheid omtrent de betekenis van de verklaring ${ }^{1}$, en anderzijds de toepasbaarheid van de standaardverklaring (onnodig) beperkt ${ }^{2}$. Ter ondervanging van deze bezwaren stelt hij vervolgens voor om de term 'vermogen' te vervangen door 'financiële positie'. In het navolgende zullen enige kritische kanttekeningen bij dit voorstel geplaatst worden en zal tevens de door Bindenga aan de term 'getrouw' toegekende betekenis aan een kritische beschouwing worden onderworpen.

In paragraaf 2 wordt daartoe allereerst ingegaan op de betekenis van de term 'vermogen', terwijl in paragraaf 3 wordt stilgestaan bij de betekenis van de door Bindenga voorgestelde vervangende term 'financiële positie'. In paragraaf 4 wordt vervolgens de verhouding van Bindenga's terminologische kwestie tot het fundamentele probleem van het, door het hanteren van de huidige standaardverklaring, ontstaan van onduidelijkheid ten principale ter discussie gesteld. De vijfde paragraaf geeft enige kritische beschouwingen betreffende de door Bindenga voorgestelde invulling van de term 'getrouw'. Paragraaf 6 geeft tenslotte een korte samenvatting van het behandelde. 


\section{De betekenis van de term 'vermogen'}

Van Dale (1984) geeft de - binnen de onderhavige context van belang zijnde - volgende omschrijving van de term 'vermogen':

'het geheel van iemands bezittingen aan goederen en rechten (activa en passiva), hetgeen hij rijk is na aftrek der passiva.'

Hieruit blijkt dat het vermogen een samenstel van bezittingen en schulden representeert. Om het vermogen in één grootheid tot uitdrukking te brengen, zullen de samenstellende bezittingen en schulden dan ook tot één rioemer herleid moeten worden. In de westerse wereld geschiedt dit normaliter door het in geldswaarde uitdrukken van de verschillende activa en passiva. Het vermogen wordt dan ook normaal gesproken in financiële termen uitgedrukt.

Door het tot één financiële grootheid herleiden van het vermogen introduceert men een waarderingsproblematiek. Activa en passiva bezitten immers niet zonder meer een éénduidig vaststelbare geldswaarde, doch moeten door hantering van bepaalde waarderingsregels in een zekere geldswaarde worden uitgedrukt. Alhoewel de geldswaarde van een object theoretisch gezien gelijk is aan de geldgenererende potentie van het object - waarbij uiteraard rekening moet worden gehouden met de tijdswaarde van het geld - hebben praktische en theoretische bezwaren tegen deze waarderingsregel desondanks geleid tot een breed scala van in de praktijk usantiële, afwijkende waarderingsregels. Wij noemen slechts ter illustratie:

- waardering tegen historische marktprijzen;

- waardering tegen actuele marktprijzen;

- waardering volgens de minimumwaarderingsregel, en

- waardering op grond van taxaties.

Het vorenstaande heeft Brezet (1986), pag. 244 aanleiding gegeven tot het plaatsen van de volgende opmerking:

' "Vermogen" moet hierbij (...) worden geïnterpreteerd als gelduitdrukking in de ruimste zin van het woord, volgens welk waarderingssysteem dan ook bepaald.'

Terecht merkt Bindenga dan ook op dat het vermogensbegrip een zekere onbepaaldheid in zich heeft, en daardoor een zekere onduidelijkheid met zich brengt. Dat het risico van begripsverwarring hieraan inherent is, staat buiten kijf. Met name bij het bestaan van een breed scala van waarderingsmogelijkheden is het daaruit voortvloeien van een Babylonische spraakverwarring helaas niet ondenkbaar. Of de door Bindenga voorgestelde vervanging van de term 'vermogen' door de term 'financiële positie' hier een oplossing voor kan zijn, is evenwel discutabel. Vraag is zelfs, of niet juist de introductie van een nieuwe (niet éénduidig interpreteerbare) term zal voeren tot een prolongatie van de Babylonische spraakverwarring. Ter beantwoording van deze vraag zal allereerst moeten worden stilgestaan bij de betekenis van de nieuw voorgestelde term.

\section{De betekenis van de term 'financiële positie'}

Bindenga ontleent de door hem voorgestelde term 'financiële positie' aan de in de Anglo-Amerikaanse praktijk gehanteerde terminologie (Bindenga (1988), pag. 315). De term 'financiële positie' is dan ook een vertaling van de term 'financial position'. Deze ontstaansgrond van de voorgestelde term pleit echter direct al tegen in plaats van voor het gebruik van deze term! Bindenga (1988), pag. 315 merkt namelijk zelf al op:

'Bijna nergens ter wereld is het gebruikelijk bezittingen en schulden op een andere manier in de jaarrekening te presenteren dan op basis van historische kosten.'

Het in een dergelijke situatie overgaan op een beter bij de internationale termen aansluitende terminologie moet welhaast leiden tot een in internationaal verband optreden van begripsverwarring. Of zou Bindenga voor de Nederlandse situatie soms óók van het hanteren van andere waarderingsgrondslagen dan de historische kosten af willen? 
Afgezien van het vorenstaande lijkt de term 'financiële positie' echter ook inhoudelijk niet zo'n gelukkige greep te zijn. Terwijl de Anglo-Amerikaanse term 'financial position' en de Nederlandse term 'vermogen' qua usance elkaars tegenhanger zijn, blijken de beide termen elkaar qua betekenis en suggestieve waarde ook nauwelijks te ontlopen. De positie waarin men in financieel opzicht verkeert, bestaat immers uit de omvang (en samenstelling) van de financiële middelen waarover men nu en/of in de toekomst kan beschikken, ergo uit de vermogenspositie waarin men verkeert. Hoe deze vermogenspositie geïnterpreteerd moet worden, wordt ook uit het gebruik van de nieuwe term niet duidelijk. Met de door Bindenga voorgestelde terminologische ingreep schiet men dus niet veel op.

Zou men door middel van een terminologische ingreep in de verklaring tot uitdrukking willen laten komen dat het balanssaldo niet de waarde van de onderneming representeert, dan zou men voor een echt duidelijke terminologie moeten opteren. Men zou in dat geval bijvoorbeeld kunnen overgaan op de term 'boekhoudkundige positie'. Alleen dan wordt namelijk duidelijk tot uitdrukking gebracht dat het balanssaldo niet de waarde van de onderneming weergeeft, maar slechts de resultante is van een boekhoudkundig verwerkings-en waarderingsproces.

Voordat wordt overgegaan tot een terminologische aanpassing van de verklaring, loont het echter de moeite om eerst terug te gaan naar het fundamentele probleem van het, door het hanteren van de huidige standaardbewoordingen, ontstaan van onduidelijkheid omtrent de betekenis van de verklaring.

\section{De oorzaak van de spraakverwarring ten principale bezien}

Krom (1987) pag. 409 formuleert de oorzaak van het zich voordoen van begripsverwarring omtrent de betekenis van de verklaring als volgt:

'Voorts worden in de tekst van de verklaring begrippen gehanteerd die niet eenduidig gedefinieerd zijn en daarom bij het maatschap- pelijk verkeer gemakkelijk duidelijke aanleiding tot verwarring kunnen geven.'

Bij de oplossing van dit probleem kunnen er in principe twee wegen worden bewandeld.

In de eerste plaats kan men de gehanteerde begrippen vervangen door andere begrippen. Zoals in paragraaf 3 is aangetoond, moet men er daarbij voor oppassen, dat niet het ene niet éénduidig gedefinieerde begrip wordt vervangen door het andere niet éénduidig gedefinieerde begrip. Zolang men evenwel één standaardbegrip wil gebruiken voor uiteenlopende situaties, is dit probleem echter slechts oplosbaar door over te stappen op het gebruik van duidelijk nietszeggende begrippen. Zo geeft de term 'boekhoudkundige positie' duidelijk aan dat de interpretatie van het balanssaldo afhankelijk is van de gehanteerde boekhoudkundige regels, maar geeft deze term tegelijkertijd aan dat de desbetreffende grootheid nietszeggend is, indien men geen inzicht heeft in die regels. Onzes inziens is het dan ook een heilloze weg om te proberen om uiteenlopende situaties met één standaardterm (zinvol) te omschrijven.

De tweede weg die bewandeld kan worden, bestaat uit het nader gaan definiëren van de ontoereikend gedefinieerde begrippen. Daarmee is men dan beland bij het vraagstuk betreffende de clausulering van de verklaring. Onzes inziens kan slechts door het nader toelichten van (onder andere) het vermogensbegrip duidelijkheid ontstaan met betrekking tot de betekenis van de verklaring. Daarbij lijkt ons een verwijzing naar de in de toelichting van de jaarrekening opgenomen uiteenzettingen de geëigende weg, aangezien:

1 de verklaring zelf slechts dient voor het weergeven van het accountantsoordeel omtrent de jaarrekening, en in principe juist die jaarrekening duidelijk zal moeten zijn inzake de betekenis van de er in opgenomen gegevens, en

2 de verklaring toch slechts te zamen met de jaarrekening openbaar mag worden gemaakt (artikel 26, lid 1 GBR). 
Overigens zijn wij met Vecht (1987), pag. 20 eens, dat het als een onhaalbare zaak beschouwd moet worden om voor grote groepen van gebruikers een volkomen duidelijkheid te creëren. Wel kan door een beknopte, maar duidelijke clausulering het bij deskundige en geïnteresseerde gebruikers ontstaan van begripsverwarring worden voorkomen.

Door een passende clausulering en toelichting is de standaardverklaring ook bruikbaar voor andere organisaties dan ondernemingen. Gezien de overeenkomst in betekenis van de termen 'vermogen' en 'financiële positie' lijkt het daarbij hanteren van de eerstgenoemde term ons niet bezwaarlijk. Zoals Bindenga (1988), pag. 322 meent over de financiële positie van non-profit organisaties te kunnen spreken, zo zien wij niet in waarom men in dat verband niet ook over de vermogenspositie zou kunnen spreken. Ook een dergelijke organisatie zal immers beschikken over een op zekere wijze waardeerbaar samenstel van bezittingen en schulden.

\section{De betekenis van de term 'getrouw'}

De huidige standaardtekst van de goedkeurende accountantsverklaring luidt als volgt:

'Wij hebben de jaarrekening 19.... van .......... gecontroleerd.

Op grond van dit onderzoek zijn wij van oordeel dat deze jaarrekening een getrouw beeld geeft van de grootte en de samenstelling van het vermogen van de vennootschap op ......... 19... en van het resultaat over 19....'

Binnen deze tekst vormt het woord 'getrouw' het hart van de verklaring. Juist door middel van dit woord geeft de accountant immers zijn waardeoordeel omtrent de door hem gecontroleerde jaarrekening. Alhoewel men kan twisten over de exactere betekenis van het begrip getrouw, zal de positieve, betrouwbaarheid en juistheid suggererende strekking van dit begrip een ieder duidelijk zijn. Bindenga (1988), pag. 323 vindt desalniettemin een exactere formulering van het in de verklaring gegeven waarde-oordeel wenselijk, hetgeen hem de volgende tekst doet voorstellen:
'Wij hebben de jaarrekening ......... van .......... gecontroleerd.

Op grond van ons onderzoek zijn wij van oordeel dat deze jaarrekening is samengesteld in overeenstemming met (..........). De resultaten over .......... en de financiële positie op worden daarom in deze jaarrekening getrouw weergegeven.' (acc. ao.)

Voor ondernemingen dient daarbij te worden verwezen naar Titel 8 Boek 2 BW, bij de overheid naar comptabiliteitswetten, bij een ziekenhuis naar Koninklijke Besluiten, etc.

De hierbij aan de term 'getrouw' toegedichte betekenis impliceert onzes inziens evenwel:

1 een flagrante onderschatting van het door de verklaring tot uiting gebrachte waarde-oordeel;

2 een niet altijd correcte en duidelijke hantering van het woord getrouw, en

3 een overbodige hantering van het woord getrouw.

De door Bindenga voorgestelde tekst onderschat het door de verklaring tot uiting gebrachte waarde-oordeel, doordat de verklaring daardoor degenereert tot een louter juridisch geclausuleerde verklaring. Het accountantsoordeel impliceert namelijk meer dan het enkele feit, dat de jaarrekening aan de desbetreffende voorschriften voldoet. Op grond hiervan zou dus hooguit gesteld kunnen worden dat de jaarrekening mede daardoor een getrouw beeld geeft.

Ook dit laatste hoeft evenwel niet per definitie het geval te zijn. Het voldoen aan bepaalde van toepassing zijnde voorschriften, behoeft immers geenszins te betekenen dat dat ook te allen tijde een bijdrage levert aan de getrouwheid van het door de jaarrekening gegeven beeld. Bij het uitvaardigen van voorschriften inzake de jaarrekening kunnen naast het getrouwheidselement namelijk ook andere aspecten een rol spelen, waardoor de vermogenspresentatie mede beïnvloed wordt door die andere aspecten. Oosenbrug $(1986 a+b)$ schetst bijvoorbeeld een beeld van de sterk uiteenlopende consequenties die het vanuit verschillende invalshoeken (in casu vanuit de aandeelhouders- c.q. de polishoudersvisie) 
opstellen van voorschriften voor de jaarrekening kan hebben voor de vermogenspresentatie. Om daarbij, ongeacht de uit de verschillende voorschriften voortvloeiende vermogenspresentaties sec, te spreken over een getrouw beeld, indien het beeld maar binnen de desbetreffende juridische context 'getrouw' is, lijkt ons niet correct en verwarring wekkend.

Tenslotte zij opgemerkt, dat in de voorgestelde tekst van de verklaring de derde volzin in feite niets aan de inhoud van de verklaring toevoegt. Zodra de getrouwheid van de jaarrekening rechtstreeks gekoppeld wordt aan het voldaan hebben aan bepaalde voorschriften, leidt vermelding van beide slechts tot een doublure. Gezien de in het spraakgebruik niet exact vaststaande betekenis van het woord getrouw, zou het uit de voorgestelde tekst schrappen van de derde volzin dan voor de hand liggen. Gezien het voorgaande lijkt het ons evenwel een beter alternatief om de bestaande standaardtekst van de goedkeurende accountantsverklaring vooralsnog te handhaven.

\section{Resumé}

De standaardtekst van de goedkeurende accountantsverklaring bevat een aantal niet exact gedefinieerde termen. Hierdoor kan er licht begripsverwarring ontstaan omtrent de betekenis van de verklaring.

Het door 'financiële positie' vervangen van de term 'vermogen' draagt echter niet bij tot het tegengaan van deze begripsverwarring. Ook dit is namelijk een niet exact gedefinieerde term, die bovendien inhoudelijk en suggestief niet wezenlijk van de huidige term verschilt. De internationale terminologie pleit daarbij eerder tegen dan voor de bedoelde substitutie.

Een fundamenteler beschouwing van het probleem leert, dat het door clausulering van de verklaring geven van, of verwijzen naar een toelichting op het gehanteerde vermogensbegrip een heilzamer weg is.

Tenslotte blijkt het rechtstreeks aan een juridische clausulering koppelen van de term 'getrouw' geen recht te doen aan de betekenis van de verklaring. Bovendien levert dit geen garanties op dat de term getrouw ook te allen tijde terecht gebruikt zal worden.

Op grond van het vorenstaande valt de huidige standaardtekst van de goedkeurende accountantsverklaring te prefereren boven het door Bindenga aangedragen alternatief.

\section{Literatuur}

Bindenga, A. J. (1988), De waarde in de accountantsverklaring, Maandblad voor Accountancy en Bedrijfshuishoudkunde, $62 \mathrm{e}$ jaargang, no. 7/8, juli/augustus 1988, pp. 313-324.

Brezet, J. C. (1986), Micro-economische en bedrijfseconomische winstbepaling, Offsetdrukkerij Kanters, Alblasserdam.

Van Dale (1984), Groot woordenboek der Nederlandse taal, Van Dale Lexicografie, Utrecht.

De tekst van de goedkeurende verklaring bij de jaarrekening, Radar, Actuele informatie voor de accountant, afd. 5.20 (losbl.), Nivra, Amsterdam.

Krom, J. P. J. (1987), Van beeld naar inhoud; op weg naar een herzien verklaringenstelsel, de Accountant, 93e jaargang, no. 9, mei 1987, pp. 408-411.

Oosenbrug, A. (1986a), 'Generally Accepted Accounting Principles' versus 'Statutory Accounting Practices' bij levensverzekeringmaatschappijen in de USA - I, het Verzekerings-Archief, deel 63-1986-3, pp. 201-210.

Oosenbrug, A. (1986b), 'Generally Accepted Accounting Principles' versus 'Statutory Accounting Practices' bij levensverzekeringmaatschappijen in de USA - II, het Verzekerings-Archief, deel 63-1986-4, pp. 255-272.

Schipper, A. P. (1988), De 'buitenzijde' van de accountantsverklaring, de Accountant, 94e jaargang, no. 11. juli/augustus 1988, pp. 518-519, 523.

Vecht, J. M. (1987), Herziening van het verklaringenstelsel: enkele kanttekeningen, de Accountant, 94e jaargang, no. 1, september 1987, pp. 20-22.

\section{Noten}

1 Vergl.: 'Het gebruik van de term vermogen in het kader van de jaarrekening roept te hoge verwachtingen op.' (Bindenga (1988), pag. 315).

2 Vergl.: 'De term vermogen kan worden vermeden, waardoor de verklaring ais standaardtekst voor alle soorten huishoudingen kan worden gebruikt.' (ibid, pag. 323). 